\title{
Reading the Transformations of an Urban Edge: From Liberty Era Palermo to the City of Today
}

\author{
By Vincenza Garofalo*
}

\begin{abstract}
To honour the battle of 27 May 1860, in 1910 the Palermo City Government decided to realise a commemorative monument. A position at the centre of a large circular plaza was of have afforded the monument a greater solemnity. The commission for the Monument was awarded to Ernesto Basile. In 1927 the City Government decided to dedicate the monument to the Fallen and asked Basile to complete the monument adding an architectural backdrop. The first version of the new project was a fence that enveloped the entire square and the ring road, interrupted only by entrances near the streets flowing into the square, and dividing it into four sectors. The final design instead called for the realisation of a semi-circular exedra of columns interrupted at the centre by a large gate that allows access to the square and to the back of the monument. The successive development of the city engulfed the square in the midst of tall and anonymous buildings realised, beginning in the 1960s, without any order of relations, stripping the surrounding fabric of its identity. Through the survey of the today's configuration, the analysis of Basile's original drawings and the representation of the modifications made over time, this text proposes an original reading of the configuration of Piazza Vittorio Veneto and the Monument to the Fallen, in relation to important moments in its history, from its design to the present day. The three-dimensional models reproduce the monument and its surroundings at the time of its construction in 1910, based on the first version for its expansion (unbuilt), with the addition of the exedra from 1930 and in its current condition. The redesign and extrapolation of different views of the digital models also provided original images of use to new readings of the perception of this space.
\end{abstract}

\section{Introduction}

To honour the fiftieth anniversary of the battle of 27 May 1860, when Garibaldi and the Thousand defeated the Bourbons at the Admiral's Bridge and entered Palermo, decreeing the annexation of Sicily to the Kingdom of Italy, in 1910 the Palermo City Government decided to realise a commemorative monument. The site initially selected for the triumphal arch, in proximity to the theatre of the battle, was the quadrivium between Via Lincoln, Via Garibaldi and Corso dei Mille, near the Admiral's Bridge, a symbolic site of the battle and now part of an Arab-Norman itinerary declared a UNESCO World Heritage Site. The successive location was, instead, very far from the former, at the far end of the extension of Via Libertà, one of the city's primary axes, the first section of which had been completed between 1848 and 1849 by the Sicilian Revolutionary Government presided over by Ruggero Settimo. ${ }^{1}$ A position at the centre of a large circular plaza, yet to be realised - today's Piazza Vittorio Veneto - with a diameter

\footnotetext{
*Assistant Professor, University of Palermo, Italy.

1. See C. De Seta and L. Di Mauro, Palermo (Bari: Editori Laterza, 1988), 150.
} 
of roughly 100 meters, was of have afforded the monument a greater solemnity. The square was to have constituted the terminus of an elegant artery at the edges of the city, with the monument serving as a backdrop. The other roads leading into the plaza were to have remained secondary, to maintain a quality of isolation. ${ }^{2}$ The square was also to have represented the connecting ring with the Parco della Favorita and with the villages to the north of the city.

The Monument Commemorating the 27 May 1860 by Ernesto Basile (1909-1910)

The commission for the "Monumento commemorativo del 27 maggio 1860" was awarded by City Council in December 1909 to Ernesto Basile who did not conceal his concerns about the scale of the square, which he considered too large to host the monument, prejudicing its perception. ${ }^{3}$ Given the imminence of its inauguration, the monument was completed very rapidly, in little more than two months, by the contractor Salvatore Rutelli.

The monument designed by Ernesto Basile, constructed in limestone and white marble, consists of a large rectangular block, resting on three steps and framed at its two ends by two slightly taller pilasters, topped by decorations of garlands of leaves and woven ribbons, each surmounted by a cartouche and a crowning cornice (see Figures 1 and 2). The left cartouche bore the date 1860, the year of the battle, and the right that of its fiftieth anniversary, the year $1910 .^{4}$

2. In December 1909 Palermo City Council approved the construction of the square and the final section of Via Libertà, as far as Via Resuttana, according to the project by the engineer Giuseppe Autore. Due to bureaucratic hurdles, the works were assigned to the contractor only two months prior to the ceremony to inaugurate the monument.

3. Ernesto Basile (Palermo 1857-1932), son of the architect Giovan Battista Filippo, earned his degree in Architecture in Palermo, where he was later a University Professor and Director of the Royal Academy of Fine Arts. A leading exponent of liberty architecture in Sicily, "la sua influenza sulla cultura architettonica in Sicilia nel primo ventennio del secolo è assai grande, tanto da determinare il formarsi di una scuola che sopravvive alla sua morte e ritarda [...] la penetrazione a Palermo della cultura architettonica razionalista" (his influence on architectural culture in Sicily during the first twenty years of the 1900s was immense, to the point of creating a school that survived him and delayed [...] the penetration of rationalist architectural culture into the city of Palermo). U. Di Cristina, "Basile Ernesto," in Dizionario degli Artisti Siciliani. Architettura, I. (ed.) L. Sarullo (Palermo: Novecento, 1993), 39. He was the author of many important works in Sicily, as well as in Rome and abroad.

4. See G. Blandi, Il Monumento alla Libertà e ai Caduti. Commemorativo del 27 Maggio 1860 e Dedicato ai Caduti Siciliani in Guerra (Palermo: Edizioni Axon Sicilia, 2002); S. Caronia Roberti, Ernesto Basile e Cinquant'Anni di Architettura in Sicilia (Palermo: F. Ciuni Editore, 1935); A. Lancellotti, "Monumento Commemorativo del 27 Maggio 1860 a Palermo," in Emporium. Parole e Figure XXXII, no. 189 (1910): 236-237; E. Sessa, Ernesto Basile 1857-1932. Fra Accademismo e “Moderno”, un' Architettura della Qualità (Palermo: Flaccovio Editore, 2010). 

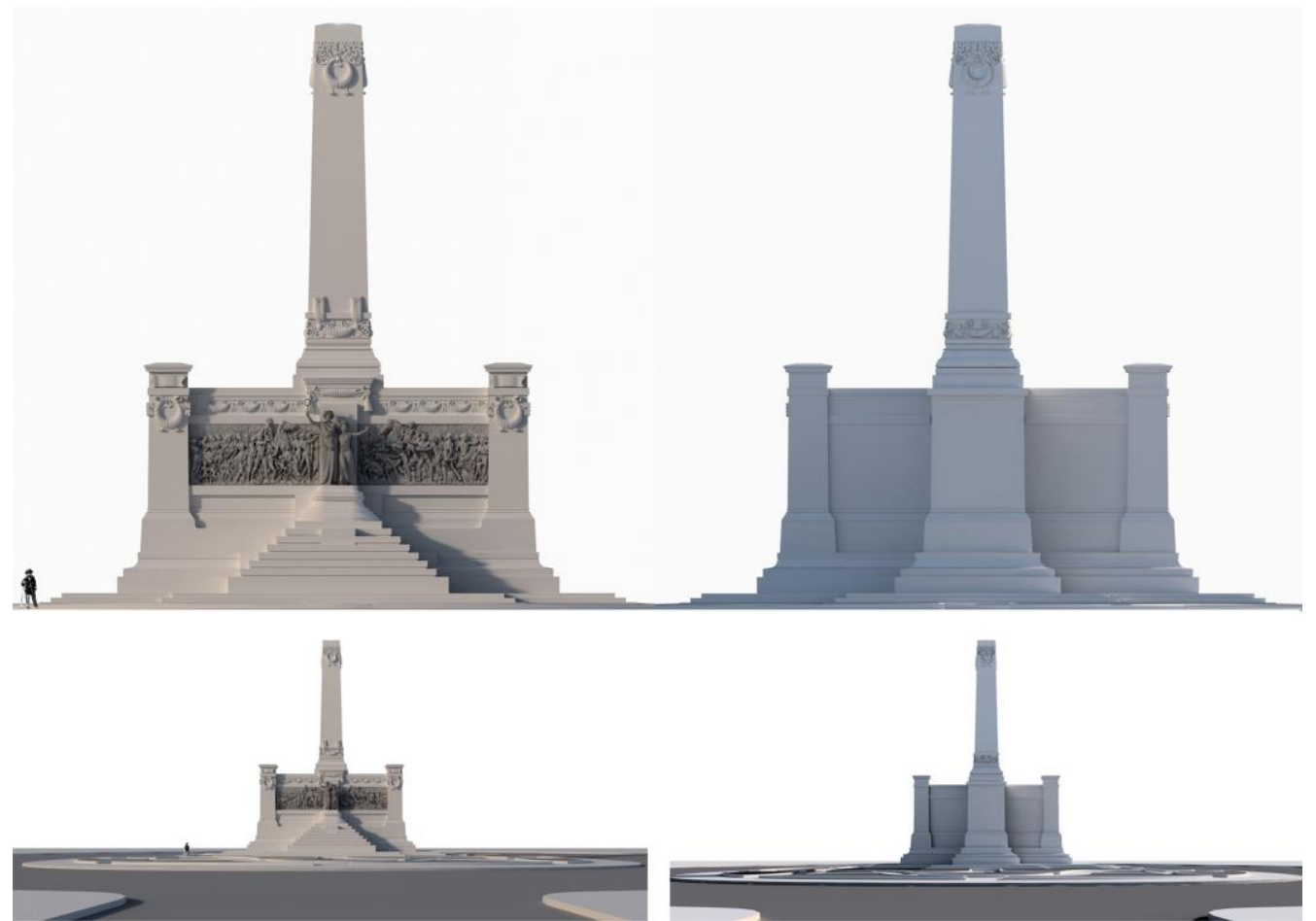

Figure 1. The Monument Commemorating the 27 May 1860. Views of the Front and Rear Faces of 3D Model (by Vincenza Garofalo)

The sculptor Antonio Ugo was entrusted with the realisation of the sculptural group for the base. ${ }^{5}$ It consists of two high-reliefs in large rectangular bronze panels, measuring 5.30 × 2.50 meters. The right panels symbolises "The Battle" and depicts a mounted Genio Italico leading the Sicilian people against the enemy. In the backdrop is a bas-relief of the Admiral's Bridge, the site of the battle. This panel is completed by depictions of armed men leaving their women, children, animals and lands to head off to battle. The left panel symbolises "The Triumph", depicting the Genio Italico bearing the symbol of Winged Victory and proceeding on horseback among the people and the survivors of the battle, preceded by the heralds of triumph. The procession is formed of a multitude of women, children and the elderly bearing baskets full of fruit, laurel wreaths, bunches of flowers and grain, symbolising the return to wellbeing, normality and reacquired freedom. The two definitive high-reliefs were installed only in 1930; in occasion of the inauguration of the monument in 1910, in their place were two temporary plaster copies, as there was insufficient time to cast the final bronzes. ${ }^{6}$

5. Antonio Ugo (Palermo 1870-1950) sculptor and professor of Plastica della Figura at the Fine Arts Academy of Palermo, he received the gold medal at the Esposizione Nazionale di Palermo of 1891-92. He collaborated on various occasions with Ernesto Basile (F. Pottino, "Antonio Ugo scultore (1870-1950)," in Atti dell' Accademia di Scienze, Lettere e Arti di Palermo XVI, serie IV, Fasc. I. (Palermo, 1990); M. A. Spadaro, "Ugo Antonio," in Dizionario degli Artisti Siciliani. Scultura, III (ed.) L. Sarullo (Palermo: Novecento, 1993), 333-335).

6. Archivio di Stato Palermo (1926-1945, 591), as reported by P. Barbera, "Monumento e Città nella Palermo Post-Unitaria," in L'Architettura della Memoria in Italia. Cimiteri, Monumenti e Città 1750-1939 (ed.) M. Giuffrè, F. Mangone, S. Pace, O. Selvafolta (Milano: Skira Editore, 2007), 

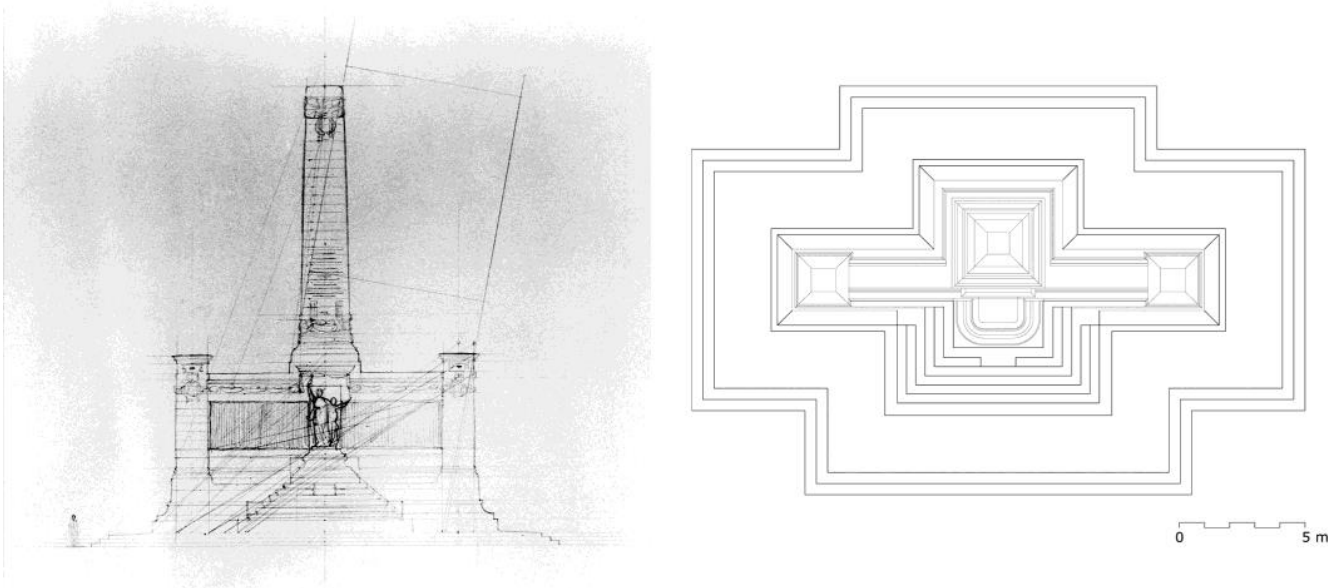

Figure 2. The Monument Commemorating the 27 May 1860. Study of Proportions (by Ernesto Basile. Source Fondo Basile). Plan (by Vincenza Garofalo)

At the centre of the monument, above a marble pedestal projecting from the base and placed atop a pyramidal stair of eight steps, is the 3.5 meter high group of bronze statues entitled "Sicily Joins the Motherland". The sculpture consists of two allegorical figures of women embracing one another, which opens toward the plaza. They are clothed in soft drapery, with crowns of laurel leaves on their heads. The largest and most majestic female figure represents Italy, the Motherland. With a proud and solemn gaze, she originally held a sceptre in her right hand, topped by a crown of oaks around a star, while her left hand grasped a smaller and younger woman, symbolising Sicily. This latter figure presents a hint of a smile of trust in the future, thanks to the freedom reacquired. In her left hand, originally, was the symbol of Winged Victory on a globe. ${ }^{7}$

On the main elevation only, a host of festoons and ribbons completes the base at the centre of which, atop its own corniced base, is an obelisk, some 28.60 meters in height. Its quadrangular tapering section is visible also from afar. The plinth at the base of the obelisk is decorated on four sides by encarpus motifs of ribbons interwoven with festoons of laurel leaves and vertical palmette; the four upper faces feature garlands of woven ribbons and branches $^{8}$ (see Figure 3 ). The primary face of the obelisk is inscribed with a commemorative epigraph by Mario Rapisardi, exalting the feats of the Thousand. "Splenda nella memoria dei secoli l'epopea del 27 maggio 1860, preparata da cuori siciliani, scritta col migliore sangue d'Italia, dalla spada prodigiosa di Garibaldi. Riecheggi nella coscienza dei popoli il tuo ruggito, o Palermo, sfida magnanima a tutte le perfide signorie, auspicio di liberazione a tutti gli oppressi del mondo."9

305 , note 29 .

7. Today, the largest female figure is without the sceptre and the star, and the smaller figure holds only the globe.

8. All of the ornamental parts of the base and the obelisk, realised in accordance with the drawings by Ernesto Basile, were engraved by the sculptor Gaetano Geraci (Palermo 1869-1931), a close collaborator of the sculptor Mario Rutelli.

9. "Shining in the memory of the centuries, the deeds of the 27 May 1860, prepared by Sicilian 

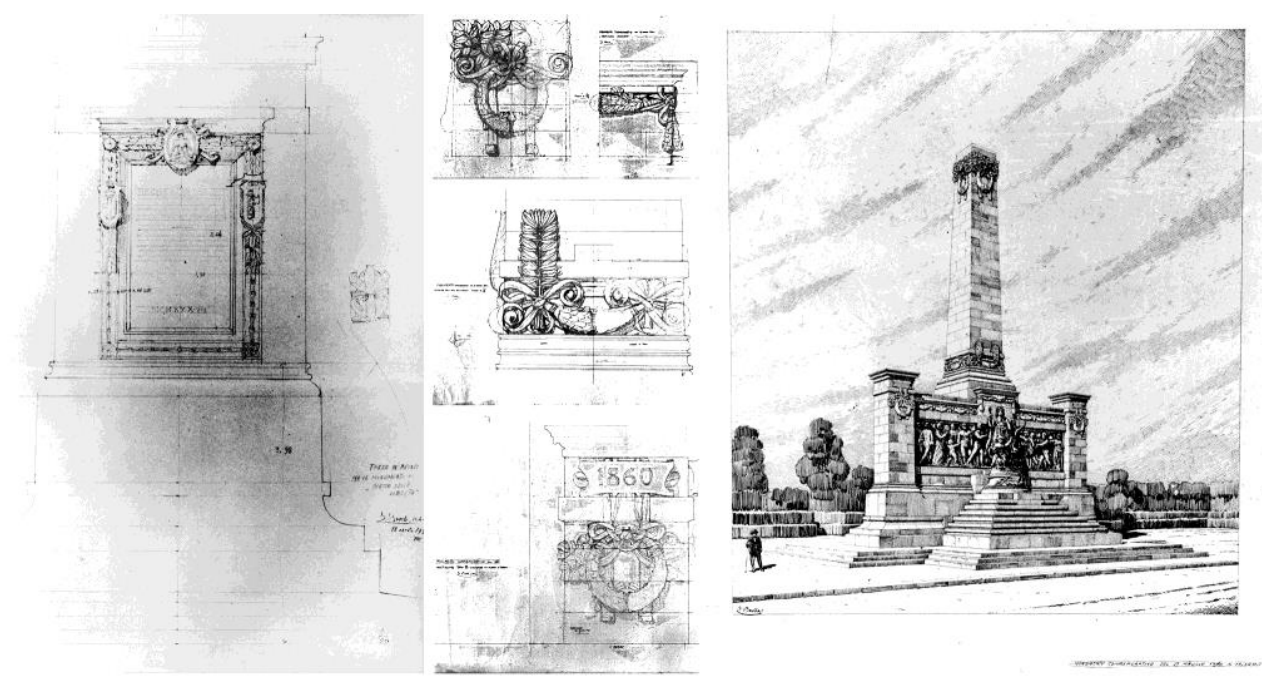

Figure 3. Preparatory Studies for Ornamental Parts: (left and top) Commemorative Plate for the Back of the Obelisk; Crowning of the Obelisk and Cornice of the Central Office; Decoration at the Base of the Obelisk; Crowning of the Pilasters. Perspective of the Monument in its Original Layout (by Ernesto Basile)

Source: Fondo Basile.

Ernesto Basile produced various studies for the monument that, despite small variations, clearly depicts the initial idea, translated into the final monument. One of his preparatory drawings also includes the study of a statue on top of the obelisk that was placed twenty years later. ${ }^{10}$

Basile also designed and built the gardens of the plaza surrounding the monument, beyond which ran a circular road that delimited and concluded this space. The selected solution, among the various proposals advanced, featured a series of hedgerows with a geometric design symmetrical with respect to the two axes of the monument, with entrances in correspondence with the streets serving the plaza (see Figure 4.) ${ }^{11}$ This design was removed in the early 1930s to obtain a larger open space for Fascist rallies.

hearts, written in the best blood of Italy, by the prodigious sword of Garibaldi. O Palermo, may your roar echo in the conscience of all peoples, as a magnanimous challenge to malicious domination and a hope for liberation from all oppressors around the globe".

10. The drawing is conserved by the Fondo Basile, Scientific Collections, Department of Architecture, at the University of Palermo.

11. The design of this solution was adopted for the layout of Piazzale Alcide De Gasperi, situated 700 meters from Piazza Vittorio Veneto, along Viale Croce Rossa, in the north-west direction. The Piazzale and the section of Viale Croce Rossa, beyond Piazza Vittorio Veneto, were realised in occasion of the 1990 World Cup. 

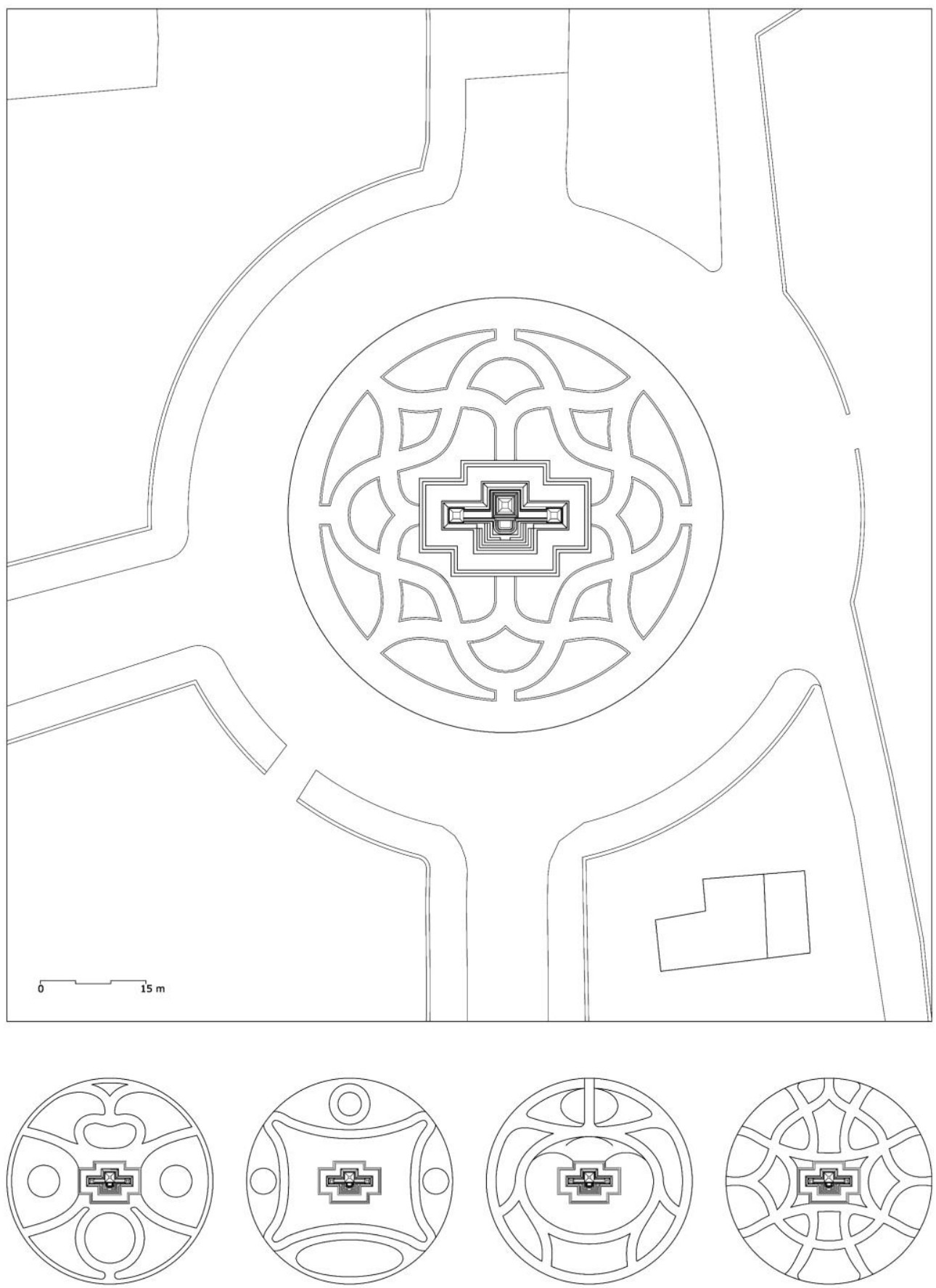

Figure 4. (From Top) The Definitive Plan of the Garden of the Monument Commemorating the 27 May 1860; Preparatory Studies (Redrawing by Vincenza Garofalo from Sketches of Ernesto Basile) 
The Colonnade by Ernesto Basile (1931) and the Consecration of the Monument to the Fallen

In 1924 the City of Palermo held a competition for the design of a monument to Sicily's fallen heroes, to be erected in a space to be identified between Piazza Vittorio Veneto, already home to the commemorative monument by Ernesto Basile. The first phase of the competition concluded with an ambiguous result and the decision was made to hold a second phase to evaluate six of the sketches presented to the first phase. The Brief for the second phase identified the definitive site for the monument inside the English Garden, along Via Libertà, a choice that would prove highly controversial. Not even the second phase produced a concrete decision. In 1927, a committee composed of the podestà, the prefect and the commander of the Armed Forces, directly awarded Ernesto Basile with the commission to realise the monument, selecting a site in the Parco della Favorita. In 1928 Basile designed an octagonal chapel with seven altars, though this version was never built. ${ }^{12}$ Finally, based on a proposal by the podestà, the decision was made to ask Ernesto Basile to transform and complete the monument he had already realised to commemorate the battle of 27 May 1860, adding an architectural backdrop that would also complete the plaza. "Ma la gerarchia tra fronte e retro del monumento, pensato sin dall'inizio come fondale della via Libertà, non può essere scardinata neanche dalla buona volontà di prefetti e podestà; e così se sul fronte si celebra l'Unità d'Italia è sul retro che viene relegata la memoria dei caduti,"14 a condition that would nurture additional, and inexistent, controversies. ${ }^{15}$

In 1930, in occasion of the celebrations of the XII anniversary of the victory of 4 November 1918, the monument would also be dedicated to Sicily's fallen during the First World War.

The top of the existing obelisk was thus crowned by a statue of "Winged Victory", realised by Mario Rutelli between 1910 and $1911 .{ }^{16}$ When this bronze

12. See writ of summons to the Basile heirs against the City of Palermo, 18 April 1934, in Archivio di Stato Palermo (1926-1945, 591), as reported by Barbera, "I Monumenti ai Caduti in Sicilia: Tra Risorgimento, Grande Guerra e Fascismo," in L' Architettura della Memoria in Italia. Cimiteri, Monumenti e Città 1750-1939 (ed.) M. Giuffrè, F. Mangone, S. Pace, O. Selvafolta (Milano: Eds. Skira Editore, 2007), 341 note 39.

13. See the Notes from the meeting held in the Prefecture on 24 January 1930 in Archivio di Stato Palermo (1926-1945, 591), as reported Barbera, "I Monumenti ai Caduti in Sicilia: Tra Risorgimento, Grande Guerra e Fascismo,” 2007, 341, note 40.

14. "However, the hierarchy between the front and back of the monument, imagined from the outset as the backdrop to Via Libertà, could not be modified even by the best intentions of prefects and the podestà; thus, while the front celebrates Italian Unity, the back is relegated to the memory of the fallen." Barbera, "I Monumenti ai Caduti in Sicilia: Tra Risorgimento, Grande Guerra e Fascismo," 2007, 339.

15. Antonio Ugo was also against this latter solution. See the writ of summons of Antonio Ugo vs. the City of Palermo, 8 October 1931 in Archivio di Stato Palermo (1926-1945, 591), as reported by Barbera, "I Monumenti ai Caduti in Sicilia: Tra Risorgimento, Grande Guerra e Fascismo," 2007, 341, note 42.

16. Mario Rutelli (Palermo 1859-1941) sculptor and professor of sculpture at the Fine Arts Academy of Palermo, was the son of Giovanni, a building contractor and collaborated with Giovan Battista Filippo Basile on the construction of the Teatro Massimo in Palermo. He completed various 
sculpture, approximately 3 meters in height, was installed, on this same occasion, a showy fasces was placed in Victory's left hand. ${ }^{17}$ Also substituted was the date 1910 on the cartouche of the right pilaster of the base, with the year 1918, the year the First World War ended. The rear façade of the base was fitted with two commemorative plaques in white marble, featuring a transcription of the war bulletin from the 4 November 1918, dictated by General Armando Diaz, calling an end to the war of 1915-18. At the centre of the rear elevation of the base, supporting the obelisk and markedly projecting from it, is a bronze plaque with a cornice, designed by Ernesto Basile himself, bearing the coat of arms of the City of Palermo at the top, to the left the coat of arms of the House of Savoy, and to the right the fasces with a dedication of the fallen from the First World War (see Figure 3).

Basile's new project, in its first version, called for the completion of the monument with a continuous masonry and steel fence, separated by columns and tall piers. The fence, erected beyond the circular road, would have enveloped the entire square and the ring road, interrupted only by entrances near the streets flowing into the square, and dividing it into four sectors (see Figures 5 and 6).

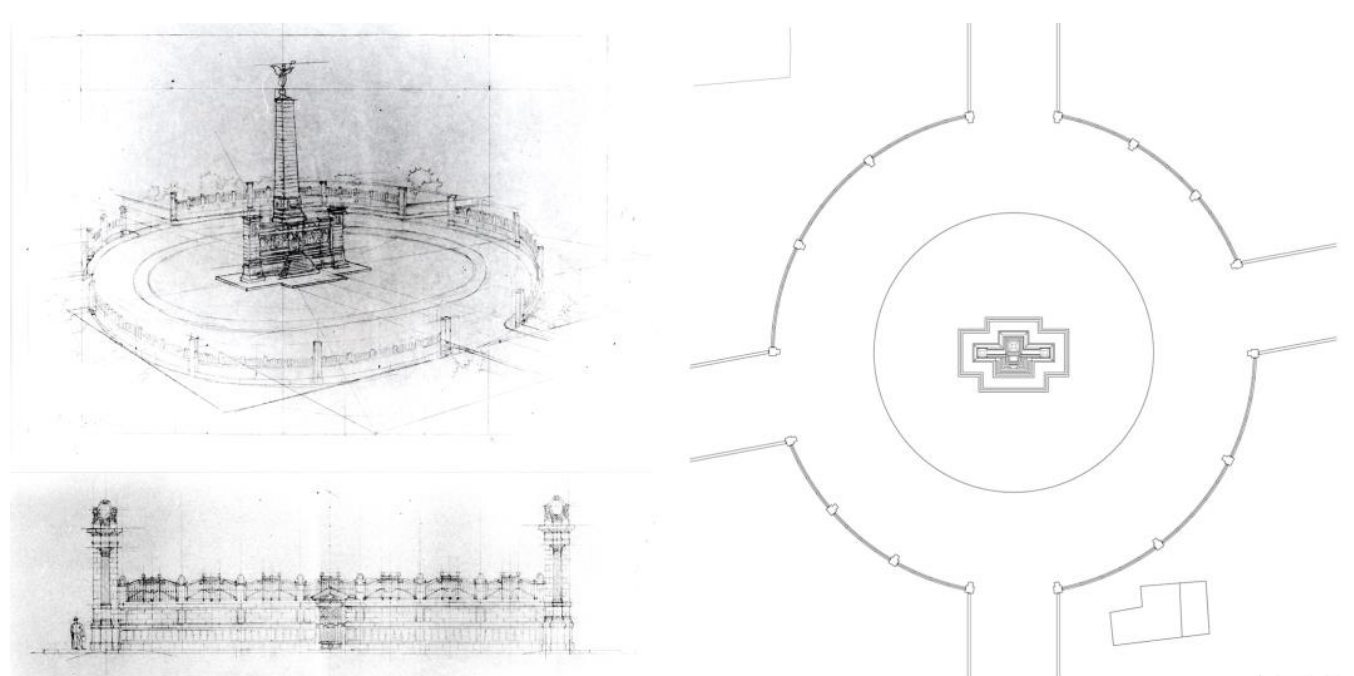

Figure 5. Monument to the Fallen: First Version of the Fence (Left and Top) Perspective and Study of a Sector (Ernesto Basile. Source Fondo Basile). (Right) Plan (Redrawing by Vincenza Garofalo)

The final design, which marked the end of Ernesto Basile's professional career, instead called for the realisation of a semi-circular exedra of columns, still

important projects in Italy and abroad. See L. Callari, Storia dell' Arte Contemporanea Italiana (Roma: Ermanno Loescher, 1909); A. Lancellotti, "Ricordo di Rutelli," in La Donna Moderna (Apr, 1942); A. Springer and C. Ricci, Manuale di Storia dell' Arte (Bergamo: Istituto Italiano d'Arti Grafiche, 1932), 490; M. A. Spadaro, "Rutelli Mario," in Dizionario degli Artisti Siciliani. Scultura, III (ed.) L. Sarullo (Palermo: Novecento, 1993), 291-292.

17. See F. Grasso (ed.) Mario Rutelli, Catalogo della Mostra, Civica Galleria d'Arte Moderna, Palermo 8 Maggio - 6 giugno 1998 (Palermo: Regione Siciliana, Assessorato dei Beni Culturali, Ambientali e della Pubblica Istruzione, 1998), 40. See the same text for its vaster bibliography. 
part of the complex, interrupted at the centre by a large gate that allows access to the square and to the back of the monument (see Figure 7). The two sectors of the exedra consist of a series of columns set atop a tall base accessed, from the concave part, via a continuous stair of four steps.
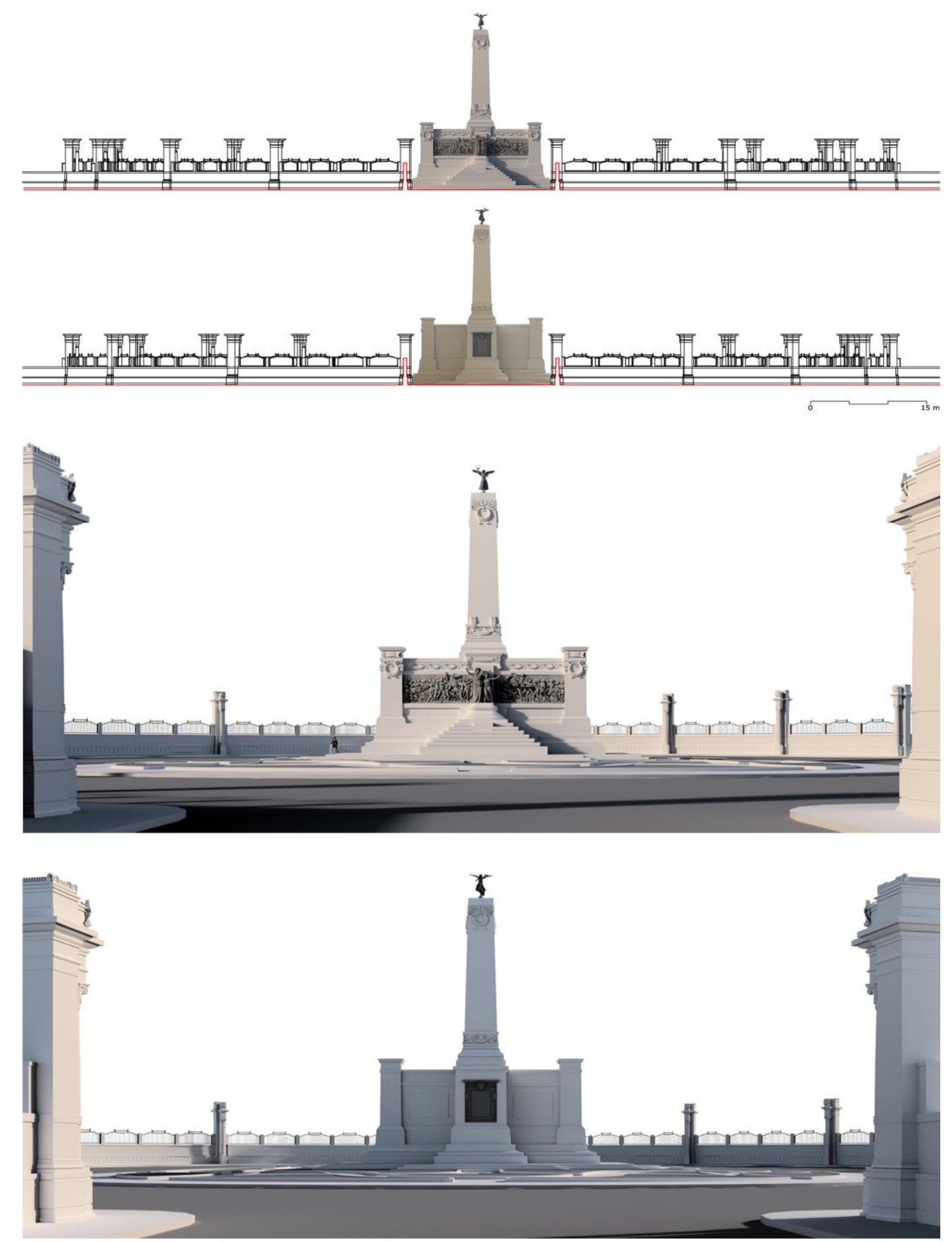

Figure 6. Monument to the Fallen: First Version of the Fence (Top) Views of the Front and Rear Faces of 3D Model (by Vincenza Garofalo) 

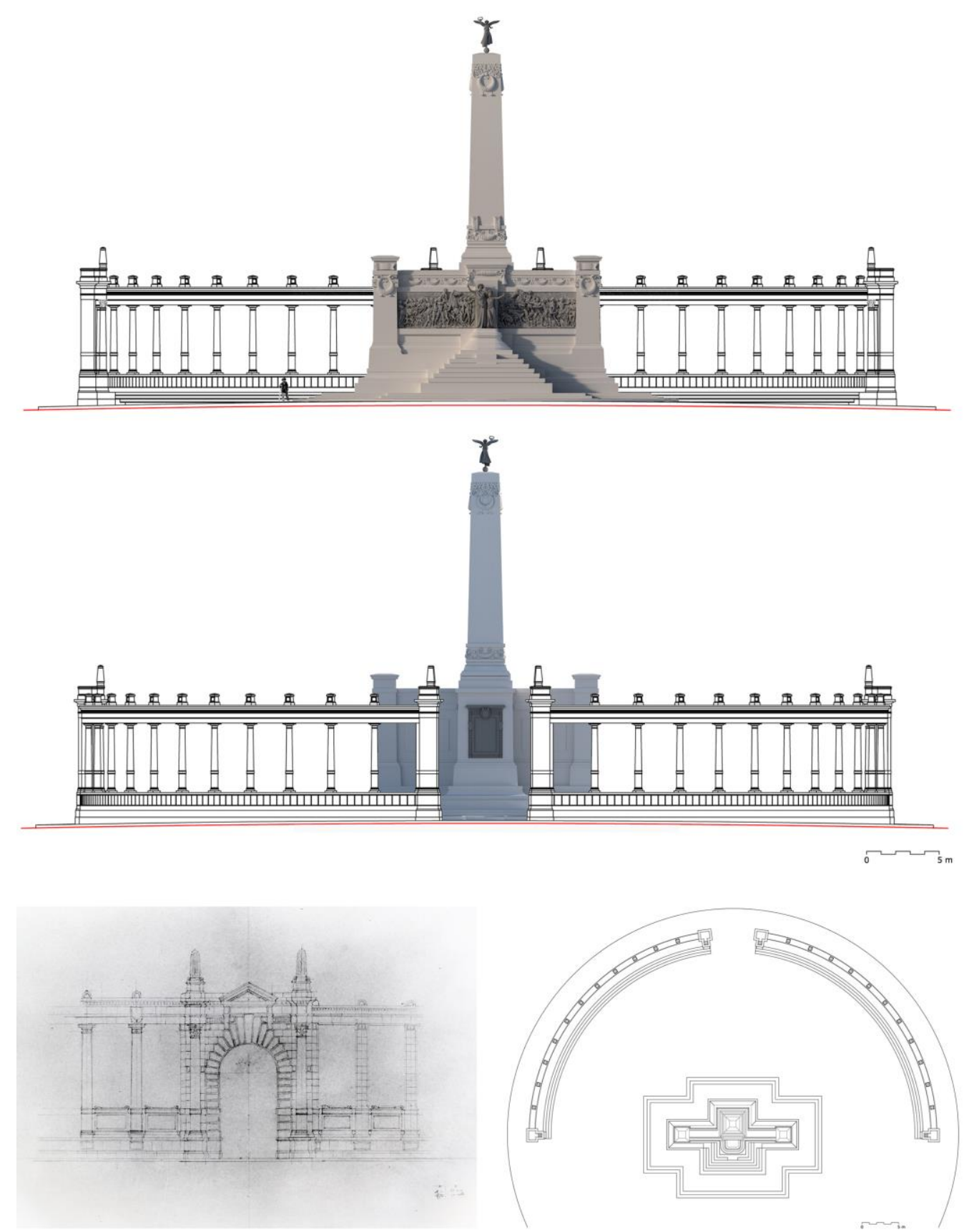

Figure 7. Monument to the Fallen: The Semi-Circular Exedra. Views of the Front and Rear Faces of the 3D Model (by Vincenza Garofalo) (Left) The Central Gate and Two Versions of the Side Bays (Ernesto Basile. Source Fondo Basile) (Right) Plan (Redrawing by Vincenza Garofalo)

The composition is completed by a continuous trabeation above which, on axis with the each column, are a series of truncated-pyramidal solids that accentuate the rhythm of the colonnade. The two circular sectors of the colonnade conclude with rectangular pylons, flanked by other columns atop which it turns back to conclude the trabeation with a soaring truncated-pyramidal solid. Along 
the trabeation, in correspondence with alternating columns at regular intervals along the inner face, are the coats of arms of the eight Sicilian provinces, with the exception of Palermo that, together with other sculptural works, were realised by Nino Geraci. ${ }^{18}$ The coat of arms of Palermo is instead located on the pylons at the ends of the two sectors of the colonnade, alternating with the symbol of the fasces. The different elements of the colonnade were realised in Billiemi marble, bardiglio grigio from the Apuan Alps, Cosimo stone and Carini tufa stone.

Opinions of this addition to the original monument were not, in the majority of cases, positive. This delusion is probably due on the one hand to a progressive rigidity of the language of Italian architecture between the two World Wars and, on the other hand, to an inexorable impoverishment of Basile's creativity, so evident in the low quality of the decorations. ${ }^{19}$

Basile "reinterpreta, con elegante vena accademica, sue soluzioni precedenti, autocitandosi per i particolari architettonici e per i repertori decorativi (...). Ne è indicativo persino il silente ellenismo del colonnato di recinzione del Monumento ai Caduti a Palermo (già Monumento Commemorativo della Redenzione Siciliana) che nel 1931 chiude la sua attività. (...) È dunque un modo di procedere riflessivo, più che compromissorio, che forse è da intendere anche come consapevole (e probabilmente anche distaccata) volontà di conferma della validità della sua precedente propositività progettuale, a prescindere dalla idoneità a fornire aggiornate risposte affini a quei recenti indirizzi estetici dei quali non si sentiva partecipe. $" 20$

\section{The New Urban Context}

When the monument was realised, it was to have constituted one of the terminal elements of the city, for which no significant expansion plan were foreseen beyond the square. Moreover, Via Libertà, to which the monument was to have served as a backdrop, represented a principal artery and no one yet imagined that the other streets arriving at the square would have played a crucial role in the city anytime in the future.

The successive development of the city, instead, engulfed the square in the midst of tall and anonymous buildings, "melma edilizia che sarebbero i nuovi quartieri medio borghesi della Palermo dei giorni nostri" ${ }^{21}$ realised, beginning in

18. Nino Geraci (Palermo 1900-1980) was the son of the sculptor Gaetano Geraci. 149.

19. See S. Dalia, Scoprire Palermo. Guida alla Città Moderna (Genova: De Ferrari, 1999),

20. "reinterpreted his previous solutions in an elegant academic vein, referencing himself in the architectural details and the repertory of decorations [...]. Indicative of this is even the silent Hellenism of the colonnade around the Monument to the Fallen in Palermo (formerly the Commemorative Monument to Sicilian Redemption) that, in 1931, ended his activities. [...] It was thus a reflexive, more than a compromised way of working, that is perhaps to be intended also as a conscious (and perhaps even detached) desire to confirm the validity of his previous design proposal, regardless of its suitability to provide updated answers comparable to the recent aesthetic approaches that he did not feel he belonged to." E. Mauro and E. Sessa (ed.) Collezioni Basile e Ducrot (Palermo: Mostra documentaria degli archivi. Edizioni Plumelia, 2014, 42).

21. "a sludge of construction that would become the new middle class districts of the Palermo 
the 1960s, without any order of relations, stripping the surrounding fabric of its identity (see Figure 8).

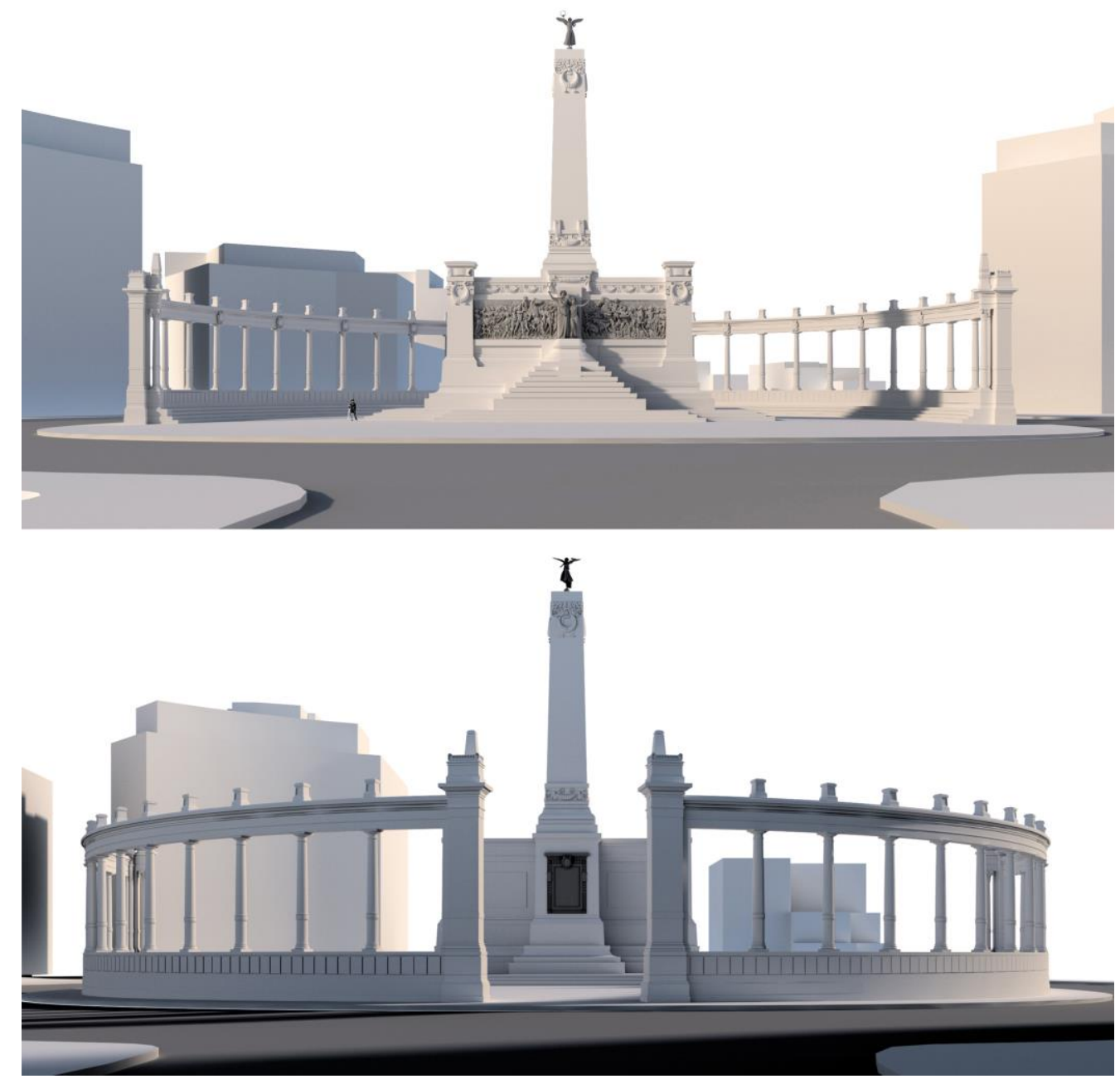

Figure 8. The Monument and the Urban Context in Today's Configuration. Perspective Views of 3D Model (by Vincenza Garofalo)

While the new colonnade embraced and ideally concluded the monument, at the same time it separated it from the ring road around it, in reality causing its isolation and introducing a variation in the very perception of the square. Furthermore, Via Libertà is now a one way vehicular artery travelled 'away' from the monument, rather than toward it. This axis continues on the other side of the monument and becomes via Croce Rossa, a wide three lane road. The square itself is now served by other roads that reduce it to a traffic clogged roundabout. The square has thus become a ring travelled by cars and trucks heading in other directions (toward the city centre, the Parco della Favorita, the stadium, the area to the north, the Villa Sofia hospital, the bypass road) and the constant and obligatory centrifugal movement contributes to the perception of a space that is little more

of today.” De Seta and Di Mauro, Palermo, 1988, 169. 
than an anonymous void. The circular path travelled by the observer conditions the perception as much of the square as the monument it contains, together with the dynamic hierarchy of the elements of which it is composed and those that define its edges. The square and the monument have lost their characteristic of being the terminus of an urban plan and their symbolic intentionality. Tall and dense trees, planted when the monument was realised, cover the view of the colonnade and contribute to the perception of a physical separation from the monument. The square has lost its architectural identity and its role as a space of coexistence and social relations. It is sufficient to consider that there are no pedestrian crossings from the external ring of the square toward the monument at its centre, which is left unnaturally void and isolated, except when it hosts official commemorations. There is no longer any continuity between the monument and the urban fabric, even if the collective imagination continues to identify with the monument and not with the space hosting it, to the point that Piazza Vittorio Veneto is commonly referred to by citizens of Palermo as La Statua (The Statue), in other words, a space of a symbolic representation that remains distant.

\section{The Drawings of Ernesto Basile}

The Fondo Basile, Scientific Collections, Department of Architecture, at the University of Palermo conserves a series of drawings relating to the Monument: 12 concerning the first configuration of the Monument Commemorating the 27 May 1860, 16 concerning the studies for the continuous fence, 20 concerning the Colonnade and the consecration of the Monument to the Fallen. ${ }^{22}$

For his drawings, partially signed and dated, Basile used pencil, charcoal, pastel, ink or china on various types of paper of different sizes.

The modus operandi adopted by Ernesto Basile was characterised by a great deal of attention toward drawing, through which the architect expressed and distinguished the creative moment of the concept and the phase of representation of the idea.

"L'approccio infatti al disegno e il conseguente ausilio dello stesso al concepimento dell'idea progettuale si costruisce attraverso un processo strutturato sulla successione di tre fasi principali nelle quali i supporti, il tratto e il tipo di rappresentazione adottata cambiano, anche in funzione di ciò che si vuole rappresentare." 23

The first phase corresponds with the creative moment when the idea is represented as lines, signs and decisive and strong sketches. During the successive phase, the idea is studied and defined; the drawing serves to verify choices only

22. See Mauro and Sessa (ed.) Giovan Battista ed Ernesto Basile. Settant' Anni di Architetture. I Disegni Restaurati della Dotazione Basile 1859-1929 (Palermo: Novecento, 2000).

23. "In fact, the approach to drawing and the consequent support it offers to the development of a design concept is constructed through a structured process based on the succession of three main phases, during which the supports, the line and the type of representation adopted change, also in relation to what is to be represented." P. Miceli (ed.) La "Professione" della Qualità. Cento Disegni a Matita di Ernesto Basile (Palermo: Grafill, 2008), 27. 
previously hinted at. During the third and final phase, which serves to verify and control the idea, the drawing extends to the level of detail.

The choice of the sign, the supports and the instruments of representation is commensurate with the importance of the drawing and its precision, with a "morbidezza del tratto per i particolari decorativi e per le linee di costruzione, precisione del tratto a grafite dura nel disegno dei prospetti e nelle linee di sezione, chiaroscuri a penna sulle prospettive, sui particolari decorativi e sui prospetti."24

This paper contains some of never-published original drawings, including a pencil one of the study of the proportions of the main front, dated 1909, which reveals a focus on symmetry and the correct correlation of the proportions between all the elements of the composition (see Figure 2). This drawing shows a possible application of the principle of analogy by Augusto Thiersch according to which harmony stems from the repetition of the same alignments between different elements to generate similar figures. ${ }^{25}$

Preparatory studies for the decorations of the monument in Piazza Vittorio Veneto (1909) are, for example, drawn in pencil, India ink and ink, with an exceptional graphic style; the friezes are designed partially in detail, with shading and chiaroscuro effects. They permit a reading of the thicknesses and an understanding of plasticity; the symmetrical other half, more basic and simplified in the style of drawing, present the geometries of the construction and its dimensions. These drawings, which constitute the tools for considering and verifying design choices, also feature annotations, sketches and calculations.

In the perspective drawing of the original design of the monument, still without the colonnade, Basile used shading to emphasise the plasticity of the composition (see Figure 3). Also represented is the wall, evident in the design of its stone blocks. The insertion of a human figure at the feet of the monument provides the proportions and dimensions of the entire design.

The series of drawings relating to the fencing of the square were realised by Basile between February and October 1930. They represent several variants of the sectors, with different studies of pylons and pedestrian entrances. These drawings also include two versions of the general planimetry in which Basile indicates four streets that converge into the square.

The drawings of the colonnade also includes several variants, realised between 1930 and 1931, and details of the trabeation, the capitals and the moldings. One of the drawings represents the central gate and two versions of the side bays (see Figure 7).

"I disegni architettonici possono senz'altro esprimere di più che non l'architettura costruita. Tecnica, stile di rappresentazione, taglio, formato, segno grafico, ductus, tutto illustra l'intenzione intellettuale dell'autore. I disegni

24. "softness of lines for decorative details and for construction lines, a precision of lines in hard pencil for elevations and section lines, chiaroscuro in ink for perspective views, decorative details and elevations." Miceli, La "Professione" della Qualità. Cento Disegni a Matita di Ernesto Basile, 2008), 28.

25. A. Thiersch, Die Proportionen in der Architektur (Stuttgart, 1904). 
d'architettura (...) acquistando un loro proprio valore artistico, possono a buon diritto proporsi come opere autonome." 26

This is true, without a shadow of a doubt, of the drawings of Ernesto Basile.

\section{A Survey of Current Conditions and the Representation of the Monument and its Urban Context}

A simultaneous comparison of IGM (Istituto Geografico Militare, or Military Geographic Institute) maps at 1:25,000 from 1912, 1937 and 1970, reveals the important changes to the area of Piazza Vittorio Veneto and its surroundings over the course of almost sixty years (see Figure 9).

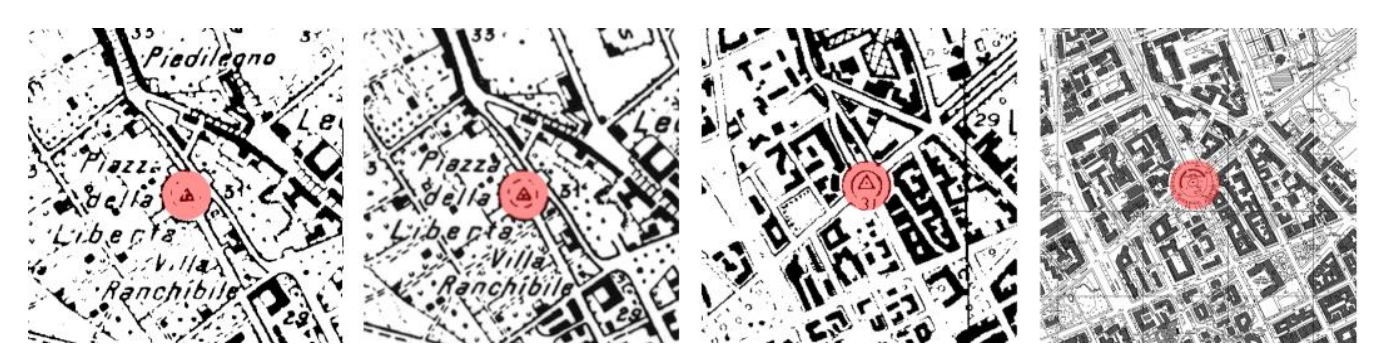

Figure 9. (from left) Piazza Vittorio Veneto. A Simultaneous Comparison of IGM Maps at 1:25.000 from 1912, 1937, 1970 and the Technical Map of 2007

The maps from 1912 and 1937 already show the square, known as Piazza della Libertà, and the monument is already represented. Neither the streets orthogonal to Via Libertà and heading toward the square, nor the extension of Via Libertà behind the monument, were completed, and the street leading to Resuttana and Villa Sofia is still visible. The area had yet to be built up, with the exception of a few isolated areas. Via Libertà was also still largely unoccupied by buildings.

In the 1970 map, the area is now shown as massively built up in the wake of a strong push toward and beyond the square. The extension of Via Libertà had not yet been realised behind the monument, though this street is now lined with a continuous row of buildings, beyond which the city extends and branches out. The layouts of Via dell' Artigliere and Via delle Brigate Verona are visible. The head toward the square and run orthogonal to Via Libertà, connecting the square with the entrance to the Parco della Favorita to the east and Viale Piemonte to the west. These streets were also laid out in the plan of Palermo from the 1950s drawn up by the Istituto Geografico Visceglia, in which the square already bears its current name.

The monument was represented, in its current configuration, as a Monge projection and in three-dimensional virtual reconstructions, based on a Structure

26. "Architectural drawings can without a doubt express more than built architecture. Technique, style of representation, view, format, graphic signs, ductus, all illustrate the author's intellectual intention. Drawings of architecture [...] acquire their own artistic value, and can in their own right be proposed as autonomous works." V. Magnago Lampugnani, La Realtà dell' Immagine. Disegni di Architettura nel Ventesimo Secolo (Stoccarda: Edizioni di Comunità, 1982), 6. 
from Motion survey (see Figure 10). Such techniques permit the extraction, from a set of photographs, of a point cloud (as by the use of a scanner laser) or a threedimensional numerical model that maintains the colour values of each point, resulting in a more realistic overall effect. ${ }^{27}$
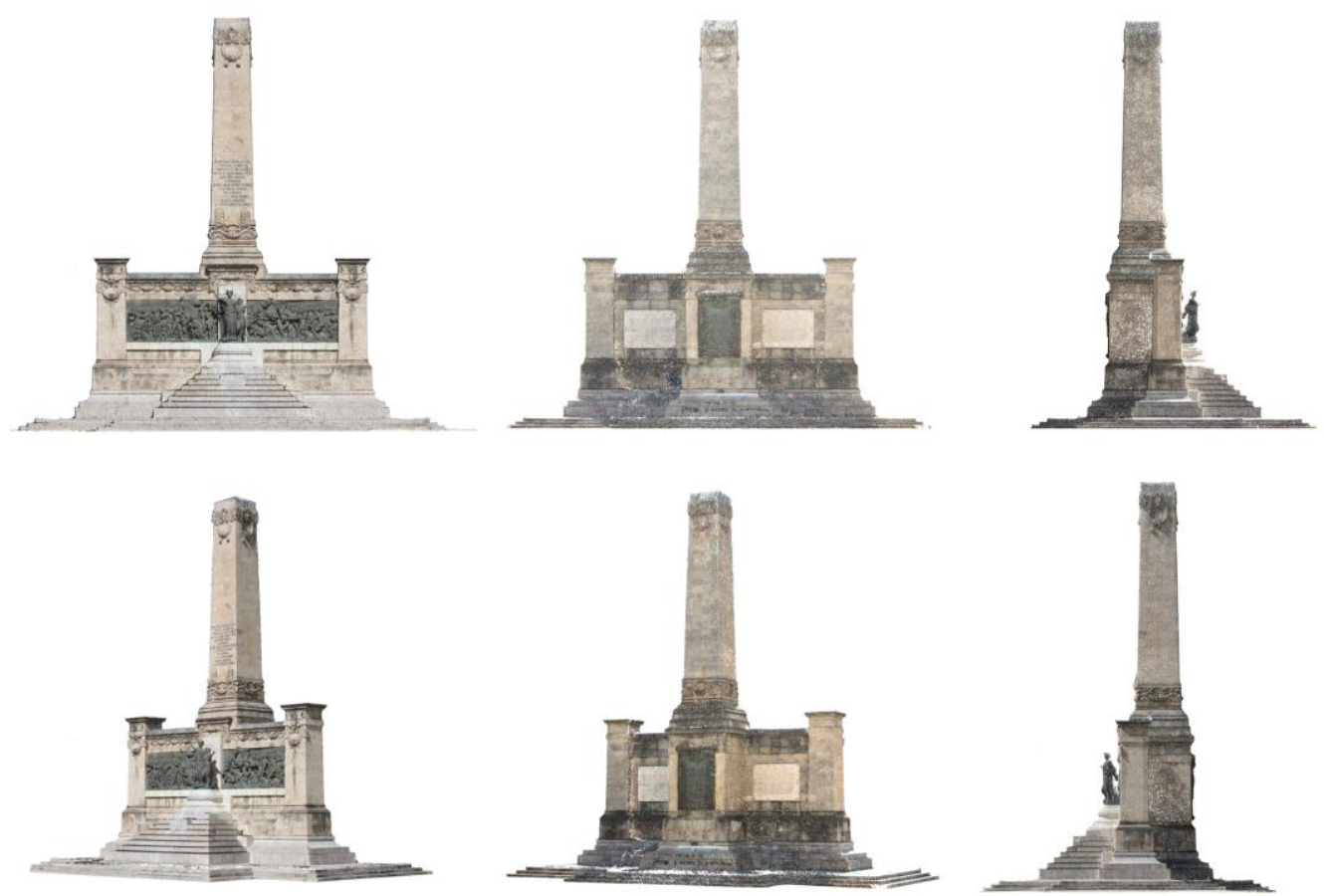

Figure 10. Survey Structure from Motion (by Vincenza Garofalo)

The pictures must be captured with the intent of ensuring an overlap between the images of at least 2/3. Dedicated software recognises homologous pixels in different images, identifying the spatial coordinates of the recognisable points and, after making the automatic collimation, generates a point cloud that is used to process the 3D model. ${ }^{28}$ From the knowledge of at least one real dimension, it is then possible to scale the entire object and obtain a 3D model that corresponds to the real form and size. This model can then be used to extrapolate all numerical information required, defining an ideal base for all future studies. Dedicated software performs photogrammetric processing of digital images and generates $3 \mathrm{D}$ spatial data.

This type of survey does not imply a choice of information during the phase of measured surveying, because the photographic a-critically document everything visible to the camera lens. It is during the successive phase of interpretation of the graphic result that the operator intervenes. In fact, this representation serves as the medium for transmitting an understanding of the real situation.

27. The point cloud is a very large set of points having $x, y$ and $z$ coordinates; if observed from a distance, the point cloud simulates a 3D representation of the monument.

28. The software can generate triangular meshes from the point cloud and superimpose a photographic texture extracted from the initial photos. 
The survey involved a first phase of data collection and a second critical phase of integrating the information obtained in to verify observations and hypotheses. The model of Basile's monument, from the Structure from Motion survey, presents a number of gaps owing to the presence of dense and tall trees set against the external part of the colonnade, which do not permit the full photographic coverage of the entire object of the survey. This required the integration of missing information through direct surveying and the elaboration of a reasoned model that has filled gaps with a critical attitude. ${ }^{29}$

If the digital models here are cognitive systems, "data collection" of the different projects of Basile, the single views extracted from the 3D models allow the interpretation, communication and representation of the monument and the project.

It was chosen to represent three moments of the story of the monument and its surroundings by schematic plans, frontal views, axonometric projections and perspectives. These drawings, extracted from the 3D model, depict the monument designed by Basile and reveal the spatial dynamics with respect to the urban context.

To represent the frontal views of the fence project and the final version with the colonnade, the rendered views of the model of the first version of the monument were integrated with two-dimensional drawings of the later projects. As a simulation of the design moment, such views integrate the designed architecture with the built architecture, maintaining the distinction between the two moments. Perspective representations, adopting "human eye height" points of view, provide more information on the perception of the monument from the road.

The original version of the monument in 1910, even without the current colonnade, is revealed in 3D model views in all its space force. The monument stands alone in the center of the square and this isolation gives it dignity and solemnity (Figure 11). The assonometric view reveals the clear integration between the organic language of the garden and the solemnity of the compositional lines of the monument.
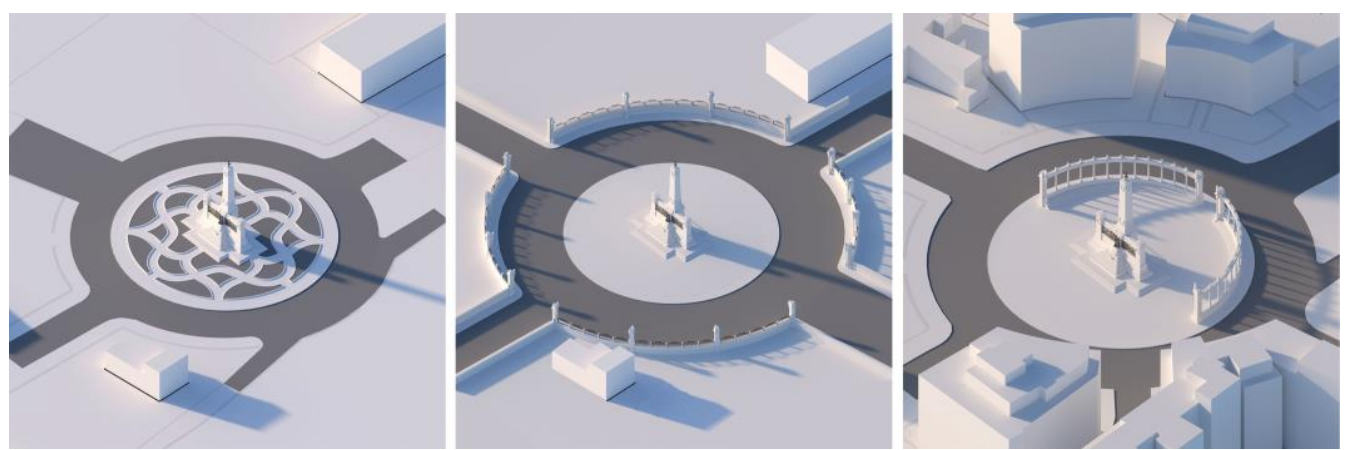

Figure 11. The Monument and the Urban Context in 1912, 1937 and Today's Configuration. Axonometric Views of 3D Model (by Vincenza Garofalo)

29. If the point cloud presents many gaps, the automatic calculation generates incorrect surfaces from the geometrical point of view. Therefore, further elaborations are needed to make "effective" the finished model. 
The views of the 3D model of the fence reveal the fragility of this project, which seemed less evident in the original drawings by Basile. The perspective views show that the fence appears too small compared to the general size of the square and the height of the monument. This solution was never realized because it was probably considered incapable of embodying the sense of a Monument to the Fallen, as well as ideologically imagined by the common sense and the need for officiality of the City Government.

The latest configuration shows that, at the time of its construction, the colonnade was a sign that underlined and surrounded the monument and ended via Libertà in an ideal hug.

The axonometric views and perspective of the current configuration show that the colonnade appears as a physical separation filter and show the loss of identity of the monument incorporated in an urban space with no more quality, among overhanging buildings that overlook it in height.

\section{Conclusions}

Through the analysis of Basile's original drawings (1909 and 1930) and the representation of the modifications made over time, this text proposes an original reading of the configuration of Piazza Vittorio Veneto and the Monument to the Fallen, in relation to important moments in its history, from its design to the present day.

For this reason the survey SfM has been carried out to realise the digital model of the current state. It was useful for the knowledge of the geometricalmorphological data of the monument, from which its past or never realised configurations have been redrawn.

The study of Basile's drawings and historic maps and photographs served to construct a digital model that includes a hypothetical reconstruction of the immediate area around the monument. The three-dimensional models reproduce the monument and its surroundings at the time of its construction in 1910, based on the first version for its expansion (unbuilt), with the addition of the exedra from 1930 and in its current condition (see Figure 11).

These digital models make it possible to represent configurations of the monument that no longer exist, or which were never realised, together with hypothetical reconstructions of its immediate surroundings that, already at the outset, possessed their own autonomy with respect to the current city. Exploring spaces and volumes that no longer exist, they are unable to express any mimetic relationship with reality.

The redesign and extrapolation of different views of the digital models also provided original images of use to new readings of the perception of this space. They are not intended as efficacious three-dimensional illusions, but merely serve to aid the comprehension of the object of study.

The drawing cannot be considered as the equivalent of architecture and cannot take its place: it tends to explain it and to reveal its historical and theoretical 
structure, it allows the careful reflection on the architecture of history and memory and on that of desire and invention. ${ }^{30}$

\section{Acknowledgments}

The original drawings by Ernesto Basile illustrating this essay are conserved by the Fondo Basile, Scientific Collections, Department of Architecture, at the University of Palermo. Our thanks to Prof. Andrea Sciascia, Director of the Department of Architecture at the University of Palermo and Proff. Carla Quartarone and Ettore Sessa, Scientific Coordinators of the Department's Scientific Collections, for allowing to consult and publish the original drawings of Ernesto Basile presented in this short text. Our thanks also to Prof. Fabrizio Agnello for processing point cloud extracted from the survey SFM.

\section{Bibliography}

Barbera P. "Monumento e Città nella Palermo Post-Unitaria." [Monument and City in the Post-Unification Palermo.] In L'Architettura della Memoria in Italia. Cimiteri, Monumenti e Città 1750-1939. Edited by M. Giuffrè, F. Mangone, S. Pace, O. Selvafolta. Milano: Skira Editore, 2007, 299-305.

"I Monumenti ai Caduti in Sicilia: Tra Risorgimento, Grande Guerra e Fascismo." [Monuments to the Fallen in Sicily: Between Risorgimento, Great War and Fascism.] In L' Architettura della Memoria in Italia. Cimiteri, Monumenti e Città 1750-1939. Edited by M. Giuffrè, F. Mangone, S. Pace, O. Selvafolta. Milano: Skira Editore, 2007, 333-343.

Blandi G. Il Monumento alla Libertà e ai Caduti. Commemorativo del 27 Maggio 1860 e Dedicato ai Caduti Siciliani in Guerra. [The Monument to Freedom and the Fallen. Commemorative of May 27, 1860 and Dedicated to the War Dead Sicilians.] Palermo: Edizioni Axon Sicilia, 2002.

Callari L. Storia dell' Arte Contemporanea Italiana. [History of Italian Contemporary Art.] Roma: Ermanno Loescher, 1909.

Caronia Roberti S. Ernesto Basile e Cinquant'Anni di Architettura in Sicilia. [Ernesto Basile and the Fiftieth Year of Architecture in Sicily.] Palermo: F. Ciuni Editore, 1935.

Dalia S. Scoprire Palermo. Guida alla Città Moderna. [Discover Palermo. Guide to the Modern City.] Genova: De Ferrari, 1999, 149.

De Seta C. and L. Di Mauro. Palermo. Bari: Editori Laterza, 1988.

Di Cristina U. "Basile Ernesto." In Dizionario degli Artisti Siciliani. Architettura, I. Edited by L. Sarullo. Palermo: Novecento, 1993, 38-40.

Florio R. Sul Disegno. Riflessioni sul Disegno di Architettura. [About Drawing. Reflections about Architectural Drawing.] Roma: Officina Edizioni, 2012.

Grasso F. (Ed.) Mario Rutelli, Catalogo della Mostra. [Mario Rutelli, Catalogue of the Exhibition.] Civica Galleria d'Arte Moderna, Palermo 8 Maggio - 6 giugno 1998.

30. See R. Florio, Sul Disegno. Riflessioni sul Disegno di Architettura (Roma: Officina Edizioni, 2012), 24. 
Palermo: Regione Siciliana, Assessorato dei Beni Culturali, Ambientali e della Pubblica Istruzione, 1998, 40.

Lancellotti A. "Monumento Commemorativo del 27 Maggio 1860 a Palermo." [Memorial Commemorating May 27, 1860 in Palermo.] In Emporium. Parole e Figure XXXII, no. 189 (1910): 236-237.

"Ricordo di Rutelli." [A Remembrance of Rutelli.] In La Donna Moderna (Apr, 1942).

Magnago Lampugnani V. La Realtà dell' Immagine. Disegni di Architettura nel Ventesimo Secolo. [The Reality of the Image. Architectural Drawings in the Twentieth Century.] Stoccarda: Edizioni di Comunità, 1982.

Mauro E. and E. Sessa (Ed.) Giovan Battista ed Ernesto Basile. Settant' Anni di Architetture. I Disegni Restaurati della Dotazione Basile 1859-1929. [Giovan Battista and Ernesto Basile. Seventy Years of Architecture. The Restored Drawings of the Basile Archive 1859-1929.] Palermo: Novecento, 2000, 250-253.

(Ed.) Collezioni Basile e Ducrot. [Basile and Ducrot Collections.] Palermo: Mostra Documentaria Degli Archivi. Edizioni Plumelia, 2014, 274-275.

Miceli P. (Ed.) La "Professione" della Qualità. Cento Disegni a Matita di Ernesto Basile. [The "Profession" of Quality. One Hundred Pencil Drawings by Ernesto Basile.] Palermo: Grafill, 2008.

Pottino F. "Antonio Ugo Scultore (1870-1950)." [Antonio Ugo, Sculptor (1870-1950).] In Atti dell' Accademia di Scienze, Lettere e Arti di Palermo XVI, serie IV, Fasc. I. Palermo, 1990.

Sessa E. Ernesto Basile 1857-1932. Fra Accademismo e "Moderno", un' Architettura della Qualità. [Ernesto Basile 1857-1932. Between Academism and "Modern", an Architecture of Quality.] Palermo: Flaccovio Editore, 2010.

Spadaro M. A. "Ugo Antonio." In Dizionario degli Artisti Siciliani. Scultura, III. Edited by L. Sarullo. Palermo: Novecento, 1993, 333-335. . "Rutelli Mario." In Dizionario degli Artisti Siciliani. Scultura, III. Edited by L. Sarullo. Palermo: Novecento, 1993, 291-292.

Springer A. and C. Ricci. Manuale di Storia dell' Arte. [Manual of Art History.] Bergamo: Istituto Italiano d'Arti Grafiche, 1932, 490.

Thiersch A. Die Proportionen in der Architektur. [The Proportions in Architecture.] Stuttgart, 1904. 